\section{JURNAL EKONOMI EFEKTIF}

ISSN : $2622-8882$, E-ISSN : 2622-9935

Jurnal Ekonomi Efektif, Vol. 1, No. 4, Juli 2019

@Prodi Manajemen Fakultas Ekonomi Universitas

Pamulang

\title{
PENGARUH CURRENT RATIO TERHADAP GROSS PROFIT MARGIN PADA PT. MEDIKA SARANA DI JAKARTA PERIODE 2009-2018
}

\author{
Arif Surahman \\ Universitas Pamulang, Tangerang Selatan, Banten Indonesia \\ *dosen01176@unpam.ac.id
}

\begin{abstract}
ABSTRAK
Penelitian ini bertujuan untuk mengetahui pengaruh Current Ratio terhadap Gross Profit Margin pada PT. Medika Sarana di Jakarta. Metode yang digunakan adalah explanatory research. Teknik analisis menggunakan analisis statistik dengan pengujian regresi, korelasi, determinasi dan uji hipotesis. Hasil penelitian ini variabel Current Ratio diperoleh nilai ratarata sebesar 583,22. Variabel Gross Profit Margin diperoleh nilai rata-rata 44,251\%. Current Ratio berpengaruh positif dan signifikan terhadap Gross Profit Margin dengan nilai persamaan regresi $\mathrm{Y}=60,448-0,063 \mathrm{X}$, dan nilai koefisien korelasi -0,760 atau memiliki tingkat hubungan yang sedang dengan nilai determinasi 57,7\%. Uji hipotesis diperoleh signifikansi 0,011>0,05.
\end{abstract}

Kata Kunci: Current Ratio, Gross Profit Margin.

\section{ABSTRACT}

This study aims to determine the effect of Current Ratio on Gross Profit Margin at PT. Medika Sarana in Jakarta. The method used is explanatory research. The analysis technique uses statistical analysis with regression testing, correlation, determination and hypothesis testing. The results of this research variable Current Ratio obtained an average value of 583.22. The Gross Profit Margin variable obtained an average value of $44.251 \%$. Current Ratio has a positive and significant effect on Gross Profit Margin with a regression equation value of $Y=60.448-0.063 X$, and a correlation coefficient value of -0.760 or has a moderate level of relationship with a determination value of $57.7 \%$. Hypothesis testing obtained a significance of $0.011>0.05$.

Keywords: Current Ratio, Gross Profit Margin. 


\section{PENDAHULUAN}

\section{A. Latar Belakang Masalah}

Meningkatnya persaingan usaha dan semakin rumitnya situasi yang dihadapi oleh perusahaan modern masa kini menuntut ruang lingkup dan peran seorang manajer yang semakin luas. Perusahaan melalui manajer keuangan dengan benar dan efisien. Ukuran yang digunakan untuk menilai keberhasilan seorang manajer keuangan dalam mengelola keuangan perusahaan adalah dengan melihat nilai perusahaan. Perusahaan pada umunya didirikan bertujuan untuk memperoleh laba yang optimum. Laba dapat dihasilkan apabila perusahaan memiliki kemampuan untuk mengelola modal yang ada secara efektif. Dimana setiap aktivitas perusahaan yang berupa transaksi dalam rangka menghasilkan laba dicatat, diklasifikasikan, dan disajikan dalam laporan keuangan. Setiap perusahaan dalam mengelola keuangan perusahaan memerlukan analisis yang dapat digunakan untuk mengukur kinerja keuangan selama periode tertentu.

Jenis rasio keuangan yang digunakan dalam penelitian ini, yaitu Rasio Likuiditas dan Rasio Profitabilitas. Rasio likuiditas merupakan suatu indikator mengenai kemampuan perusahaan membayar semua kewajiban finansial jangka pendek pada saat jatuh tempo dengan menggunakan aktiva lancar yang tersedia. Likuiditas tidak hanya berkenan dengan keadaan keseluruhan keuanganperusahaan, tetapi juga berkaitan dengan kemampuannya mengubah aktiva lancar tertentu menjadi uang kas. Secara data empiris perkembangan Current Ratio diperoleh dari perbandingan Aktiva Lancar dengan Hutang Lancar pada tahun yang bersangkutan. Berikut perkembangan Current Ratio pada PT. Medika Sarana di Jakarta periode tahun 2009-2018.

Tabel 1. Data Empiris Perkembangan Current Ratio PT. Medika Sarana di Jakarta Tahun 2009-2018

\begin{tabular}{|c|c|c|}
\hline Tahun & Curent Ratio (\%) & Gross Profit Margin (\%) \\
\hline 2009 & 335.27 & 45.87 \\
\hline 2010 & 340.54 & 47.91 \\
\hline 2011 & 383.93 & 47.99 \\
\hline 2012 & 340.36 & 48.88 \\
\hline 2013 & 369.78 & 43.03 \\
\hline 2014 & 413.11 & 41.97 \\
\hline 2015 & 442.33 & 41.55 \\
\hline 2016 & 398.75 & 40.78 \\
\hline 2017 & 422.72 & 41.72 \\
\hline 2018 & 375.44 & 42.81 \\
\hline Rata-rata & 382.22 & 44.25 \\
\hline
\end{tabular}

Berdasarkan data pada tabel di atas, perusahaan memperoleh current ratio rata-rata $382.23 \%$ dan nilai gross profit margin sebesar $44,25 \%$. Berdasarkan latar belakang di atas, maka penulis membuat judul penelitian "Pengaruh Current Ratio Terhadap Gross Profit Margin (GPM) Pada PT. Medika Sarana di Jakarta Periode 2009-2018.

\section{B. Rumusan Masalah}

1. Bagaimana Current Ratio pada pada PT. Medika Sarana di Jakarta ?.

2. Bagaimana Gross Profit Margin pada PT. Medika Sarana di Jakarta ?.

3. Adakah pengaruh antara Current Ratio terhadap Gross Profit Margin pada PT. Medika Sarana di Jakarta?.

\section{Tujuan Penelitian}


1. Untuk mengetahui kondisi Current Ratio pada PT. Medika Sarana di Jakarta.

2. Untuk mengetahui kondisi Gross Profit Margin pada PT. Medika Sarana di Jakarta.

3. Untuk mengetahui pengaruh antara Current Ratio terhadap Gross Profit Margin pada PT. Medika Sarana di Jakarta.

\section{METODE PENELITIAN}

\section{Populasi}

Populasi dalam penelitian ini laporan keuangan PT. Medika Sarana di Jakarta selama 10 tahun

\section{Sampel}

Teknik pengambilan sampling dalam penelitian ini adalah samplel jenuh, dimana semua anggota populasi dijadikan sebagai sampel. Dengan demikian sampel dalam penelitian ini laporan keuangan PT. Medika Sarana di Jakarta selama 10 tahun.

\section{Jenis Penelitian}

Jenis penelitian yang dipakai adalah asosiatif, dimana tujuannya adalah untuk mengetahui mencari keterhubungan antara variabel independen terhadap variabel dependennya

\section{Metode Analisis Data}

Dalam menganalisis data digunakan analisis deskriptif, analisis regresi linier sederhana, koefisien korelasi, koefisien determinasi dan uji hipotesis.

\section{HASIL PENELITIAN}

\section{Analisis Deskriptif}

Pada pengujian ini digunakan untuk mengetahui nilai minimum dan maksimum tertinggi, rata-rata dan standar deviasi dari masing-masing variabel. Adapun hasilnya sebagai berikut: Tabel 1. Hasil Analisis Descriptive Statistics

\begin{tabular}{|c|c|c|c|c|c|}
\hline \multicolumn{6}{|c|}{ Descriptive Statistics } \\
\hline & $\mathrm{N}$ & Minimum & Maximum & Mean & Std. Deviation \\
\hline Current Ratio (X) & 10 & 335.3 & 442.3 & 382.223 & 37.0860 \\
\hline Gross Profit Margin (Y) & 10 & 40.8 & 48.9 & 44.251 & 3.0901 \\
\hline Valid N (listwise) & 10 & & & & \\
\hline
\end{tabular}

Current Ratio diperoleh nilai minimum sebesar 335,3 dan nilai maximum 442.3 dengan ratarata sebesar 583,22 dengan standar deviasi 37,086. Gross Profit Margin diperoleh nilai minimum sebesar 40,8 dan nilai maximum 48,9 dengan rata-rata sebesar 44,251 dengan standar deviasi 3,090.

\section{Analisis Kuantitatif.}

Pada analisis ini dimaksudkan untuk mengetahui pengaruh variabel independen terhadap variabel dependen. Adapun hasil pengujian sebagai berikut:

\section{a. Analisis Regresi Linier Sederhana}

Uji regresi ini dimaksudkan untuk mengetahui perubahan variabel dependen jika variabel independen mengalami perubahan. Adapun hasil pengujiannya sebagai berikut:

Tabel 2. Hasil Pengujian Regresi Linier Sederhana

\begin{tabular}{c|c|c|c|c}
\multicolumn{5}{c}{ Coefficients $^{\mathbf{a}}$} \\
\begin{tabular}{c|c|c|c} 
Unstandardized Coefficients & Standardized Coefficients & & \\
B & Std. Error & Beta & Sig.
\end{tabular} \\
\hline
\end{tabular}




\begin{tabular}{|c|c|c|c|c|c|c|}
\hline \multirow[t]{2}{*}{1} & (Constant) & 68.448 & 7.352 & & 9.311 & .000 \\
\hline & $\begin{array}{l}\text { Current } \\
\text { Ratio (X) }\end{array}$ & -.063 & .019 & -.760 & -3.305 & .011 \\
\hline
\end{tabular}

a. Dependent Variable: Gross Profit Margin (Y)

Berdasarkan hasil pengujian pada tabel di atas, diperoleh persamaan regresi $\mathrm{Y}=$ 60,448 - 0,063X. Dari persamaan tersebut dijelaskan sebagai berikut:

1) Konstanta sebesar 60,448 diartikan jika Current Ratio tidak ada, maka telah terdapat nilai Gross Profit Margin sebesar 60,448 point.

2) Koefisien regresi Current Ratio sebesar -0,063, angka ini negatif artinya setiap ada penurunan Current Ratio sebesar -0,063 point maka Gross Profit Margin juga akan mengalami penurunan sebesar $-0,063$ point.

\section{b. Analisis Koefisien Korelasi}

Analisis koefisien korelasi dimaksudkan untuk mengetahui tingkt kekuatan hubungan dari variabel independen terhadap variabel dependen baik secara parsial maupun simultan. Adapun hasil pengujian sebagai berikut:

Tabel 3. Hasil Pengujian Koefisien Korelasi Current Ratio Terhadap Gross Profit Margin.

\begin{tabular}{|c|c|c|c|}
\hline \multicolumn{4}{|c|}{ Correlations $^{b}$} \\
\hline & & $\begin{array}{c}\text { Current Ratio } \\
\text { (X) }\end{array}$ & $\begin{array}{l}\text { Gross Profit } \\
\text { Margin }(Y)\end{array}$ \\
\hline \multirow[t]{2}{*}{ Current Ratio (X) } & Pearson Correlation & 1 & $-.760^{*}$ \\
\hline & Sig. (2-tailed) & & .011 \\
\hline \multirow[t]{2}{*}{ Gross Profit Margin $(Y)$} & Pearson Correlation & $-.760^{*}$ & 1 \\
\hline & Sig. (2-tailed) & .011 & \\
\hline
\end{tabular}

*. Correlation is significant at the 0.05 level (2-tailed).

b. Listwise $\mathrm{N}=10$

Berdasarkan hasil pengujian diperoleh nilai korelasi sebesar -0,760 artinya Current Ratio memiliki hubungan yang negatif kuat terhadap Gross Profit Margin.

\section{c. Analisis Koefisien Determinasi}

Analisis koefisien determinasi dimaksudkan untuk mengetahui besarnya persentase pengaruh dari variabel independen terhadap variabel dependen. Adapun hasil pengujian sebagai berikut:

Tabel 4. Hasil Pengujian Koefisien Determinasi Current Ratio Terhadap Gross Profit Margin.

\begin{tabular}{|c|c|c|c|c|}
\hline \multicolumn{5}{|c|}{ Model Summary } \\
\hline Model & $\mathrm{R}$ & R Square & $\begin{array}{l}\text { Adjusted R } \\
\text { Square }\end{array}$ & $\begin{array}{l}\text { Std. Error of the } \\
\text { Estimate }\end{array}$ \\
\hline 1 & $.760^{a}$ & .577 & .524 & 2.1309 \\
\hline
\end{tabular}

a. Predictors: (Constant), Current Ratio $(X)$

Berdasarkan hasil pengujian diperoleh nilai determinasi sebesar 0,577 artinya Current Ratio memiliki kontribusi pengaruh sebesar 57,7\% terhadap Gross Profit Margin.

\section{d. Uji Hipotesis}

Pengujian hipotesis dengan uji t digunakan untuk mengetahui hipotesis mana yang 
diterima. Rumusan hipotesis: Terdapat pengaruh yang signifikan antara Current Ratio terhadap Gross Profit Margin.

Tabel 5. Hasil Uji Hipotesis Current Ratio Terhadap Gross Profit Margin.

\begin{tabular}{|c|c|c|c|c|c|c|}
\hline & & Co & ficients $^{a}$ & & & \\
\hline & & $\begin{array}{r}\text { Unsta } \\
\text { Coe }\end{array}$ & $\begin{array}{l}\text { ardized } \\
\text { ients }\end{array}$ & $\begin{array}{l}\text { Standardized } \\
\text { Coefficients }\end{array}$ & & \\
\hline & & $\mathrm{B}$ & Std. Error & Beta & $\mathrm{t}$ & Sig. \\
\hline 1 & (Constant) & 68.448 & 7.352 & & 9.311 & .000 \\
\hline & Current Ratio (X) & -.063 & .019 & -.760 & -3.305 & .011 \\
\hline
\end{tabular}

a. Dependent Variable: Gross Profit Margin (Y)

Berdasarkan hasil pengujian pada tabel di atas, diperoleh nilai $\mathrm{t}$ hitung $>\mathrm{t}$ tabel atau $(-3,305>-2,306)$, dengan demikian hipotesis yang diajukan bahwa tidak terdapat pengaruh yang signifikan atara Current Ratio terhadap Gross Profit Margin diterima.

\section{Pembahasan Hasil Penelitian}

\section{Perkembangan Nilai Variabel Current Ratio}

Berdasarkan data empiris dan analisis data, variabel Current Ratio diperoleh nilai rata-rata per tahun sebesar 583,22.

\section{Perkembangan Nilai Variabel Gross Profit Margin}

Berdasarkan data empiris dan analisis data, variabel Gross Profit Margin diperoleh nilai rata-rata per tahun sebesar 44,251 .

\section{Pengaruh Current Ratio Terhadap Gross Profit Margin}

Current Ratio berpengaruh signifikan terhadap Gross Profit Margin dengan persamaan regresi $\mathrm{Y}=60,448-0,063 \mathrm{X}$, nilai korelasi sebesar $-0,760$ atau memiliki hubungan yang negatif kuat dengan kontribusi pengaruh sebesar 57,7\%. Pengujian hipotesis diperoleh nilai $\mathrm{t}$ hitung $>\mathrm{t}$ tabel atau $(-3,305>-2,306)$. Dengan demikian hipotesis yang diajukan bahwa terdapat berpengaruh signifikan antara Current Ratio terhadap Gross Profit Margin diterima.

\section{KESIMPULAN DAN SARAN}

\section{Kesimpulan}

a. Current Ratio diperoleh nilai minimum sebesar 335,3 dan nilai maximum 442.3 dengan rata-rata sebesar 583,22 dengan standar deviasi 37,086.

b. Gross Profit Margin diperoleh nilai minimum sebesar 40,8 dan nilai maximum 48,9 dengan rata-rata sebesar 44,251 dengan standar deviasi 3,090.

c. Current Ratio berpengaruh signifikan terhadap Gross Profit Margin dengan persamaan regresi $\mathrm{Y}=60,448-0,063 \mathrm{X}$, nilai korelasi sebesar $-0,760$ atau negatif kuat dan kontribusi pengaruh sebesar $57,7 \%$ sedangkan sisanya sebesar $42,3 \%$ dipengaruhi faktor lain. Uji hipotesis diperoleh nilai $\mathrm{t}$ hitung $<\mathrm{t}$ tabel atau $(-3,305>-2,306)$.

\section{Saran}

a. Perusahaan hendaknya mempertahankan posisi Current Ratio nya, karena dengan Current Ratio yang baik menunjukan bahwa perusahaan dapat memenuhi kewajiban jangka pendeknya, tetapi Current Ratio yang terlalu tinggi pula dapat dikatakan tidak baik karena menandakan kelebihan uang kas atau aktiva lancar yang dibutuhkan, sedangkan untuk 
besaran Current Ratio yang aman adalah 150\%. Oleh karena itu perusahaan harus mempertahankan posisi Current Ratio.

b. Perusahaan diharapkan dapat lebih meningkatkan Gross Profit Margin, agar dapat mempertahankan kelangsungan hidup perusahaan dan bahkan dapat tumbuh dan berkembang.

c. Perusahaan diharapkan dapat meningkatkan profitabiltas dengan cara melakukan survey lapangan terhadap para konsumen mengenai apa yang konsumen perlakukan, hal ini dimaksud untuk meningkatkan penjualan lebih baik lagi.

\section{DAFTAR PUSTAKA}

Fahmi, Irham. “Analisis Kinerja Keuangan”. Cetakan Kesatu, Alfabeta, Bandung,2011.

Handoko, T. Hani, "Manajemen”. Edisi kedua, cetakan keduapuluh satu, Penerbit: BPFE, Yogyakarta, 2011.

Harahap, Sofyan S. “Analisis Kritis atas Laporan Keuangan”. Edisi Kesatu. Jakarta : PT. Raja Grafindo Persada. 2007.

Harahap, Sofyan Syafri. “Analisis Kritis Laporan Keuangan”. Rajawali Pers, Jakarta,2010.

Husein, Umar. "Metode Penelitian untuk Skripsi dan Tesis Bisnis”. PT. Rajagrafindo Persada, Jakarta, 2008.

Ilham, D. (2014). Implementasi Nilai-Nilai Keagamaan pada Mata Pelajaran Umum dalam Upaya Peningkatan Akhlak Peserta Didik di MAN Malili Kabupaten Luwu

Timur (Doctoral dissertation, STAIN/IAIN Palopo).

Ilham, D. (2019). Implementing Local Wisdom Values in Bride and Groom Course at KUA Bara SubDistrict, Palopo City. Jurnal Konsepsi, 8(1), 1-9.

Ilham, D. (2019). Menggagas Pendidikan Nilai dalam Sistem Pendidikan

Nasional. Didaktika: Jurnal Kependidikan, 8(3), 109-122.

James C. Van Horne, "Pengantar Manajemen Keuangan", Edisi Pertama, Cetakan kedua, Penerbit Kencana, Jakarta, 2010.

James C. Van Horne. John M. Wachowicz, JR, "Financial Management", Edisi 12, Penerbit: Salemba Empat Jakarta, 2009.

Juhandi, Nendi. "Manajemen Keuangan Lanjutan”, Pelangi Nusantara, Jakarta, 2007.

Kasmir, "Pengantar Manajemen Keuangan”, Edisi I, Cetakan 2, Penerbit Prenada Media, Jakarta, 2010.

Kasmir. “Analisis laporan Keuangan”. Rajawali Pers, Jakarta, 2008.

Manullang, "Dasar-Dasar Manajemen”, cetakan keduapuluh satu, Penerbit: GDJAH MADA UNIVERSITY PRESS, Yogyakarta, 2009.

Martono dan Agus Harijito. "Manajemen Keuangan”. Edisi Ketiga, Ekonisia, Yogyakarta, 2010.

Muljono, Teguh Pudjo. “Analisis Laporan Keuangan untuk Perbankan”. Edisi Revisi, Cetakan Keenam, Djambatan, jakarta, 1999.

Mulyono, Agus. "Manajemen”. Edisi Ketiga, BPFE, Yogyakarta, 2001.

Munawir, "Analisis Laporan Keuangan”, Edisi Keempat, Cetakan Kelimabelas, Penerbit: LIBERTY, Yogyakarta, 2013.

Munawir, S. “Analisa Laporan Keuangan”, Edisi keempat, Cetakan keempat belas, Liberty, Yogyakarta, 2010.

Munawir. “Analisis laporan Keuangan”. Edisi Keempat, Liberty, Yogyakarta, 2010. Sekaran, Uma. "Metodologi penelittian untuk Bisnis 2". Edisi Keempat, Salemba Empat, Jakarta, 2006.

Prastowo, Dwi, Rifka Juliaty. 2002. “Analisis Laporan Keuangan-Konsep dan Aplikasi”. 
Cetakan Kedua. Yogyakarta : AMP YKPN.Brigham dan Houston. "Dasar-dasar Manajemen”. Edisi Kedua Buku Pertama, Salemba Empat, Jakarta, 2010.

Siamat, Dahlan. "Manajemen Lembaga Keuangan”. FEUI, Jakarta, 2001.

Sidharta, I., \& Affandi, A. (2016). The empirical study on intellectual capital approach toward financial performance on rural banking sectors in Indonesia. International Journal of Economics and Financial Issues, 6(3). 